\title{
HERESIA E ORTODOXIA: UMA ANÁLISE TEÓRICA NO CONTEXTO DA INQUISIÇÃO
}

\author{
HERESY AND ORTHODOXY: A THEORETICAL ANALYSIS IN THE CONTEXT OF \\ THE INQUISITION
}

\begin{abstract}
Anderson Cordeiro de Moura ${ }^{1}$
Resumo: Neste trabalho, propomo-nos a analisar o processo pelo qual a heresia torna-se realidade. Trata-se de um estudo teórico com o intuito de compreender como a ortodoxia "cria", através do seu discurso, a heresia e legitima, por meio de vários mecanismos de coerção, a intolerância. Para tanto, adotamos a pesquisa descritiva e de natureza bibliográfica, tomando como base a análise do discurso norteado por Michel Foucault (1996), que apresenta, mediante o estudo da formação discursiva de cada momento histórico, a relação entre discurso e poder, considerando dispositivos de controle do poder nas diferentes culturas e épocas históricas. Com base em nosso estudo, pretendemos evidenciar que, para que haja a heresia, é fundamental o papel da ortodoxia. Ou seja, as heresias não nascem por oposição à religião, mas de dentro da própria religião, como uma resposta crítica a ela.
\end{abstract}

Palavras-chave: Intolerância, heresia, discurso.

Abstract: In this work, we propose to analyze, the process by which the heresy becomes reality. This is a theoretical study with the aim of understanding how the orthodoxy, "creates" through its discourse of heresy, and legitimates through various mechanisms of coercion and intolerance. For both, we have adopted the descriptive nature of the literature, taking as analytical framework the discourse analysis guided by Michel Foucault (1996) that presents, through the study of the discursive formation of each historical moment, the relationship between discourse and power, whereas resistance devices and control of power in different cultures and historical periods. Based on our study, we intend to highlight that, for there to be heresy is fundamental to the role of orthodoxy. That is, heresies are not born out of opposition to religion, but rather within religion itself, as a critical response to it.

Keywords: Intolerance, heresy, speech.

\section{Introdução}

O conceito de religião provoca ainda muitas discussões e não existe um consenso a respeito do seu significado. Em muitas línguas, a palavra latina religio carrega um sentido bastante especifico, uma vez que a cultura europeia foi profundamente marcada pelo cristianismo. Quando se fala em religião, logo se remete ao cristianismo católico. Foi este

\footnotetext{
${ }^{1}$ Mestrando pelo Programa de Pós-Graduação em Ciências das Religiões da Universidade Federal da ParaíbaUFPB. Membro do VIDELICET - Estudos em Intolerância, Diversidade e Imaginário, vinculado ao PPGCR/UFPB e ao CNPq: andersoncm16@ hotmail.com
} 
sentido de religião proposto por Santo Agostinho que passou para o ocidente cristão: [...] "a ideia de que religio significava uma ligação baseada na submissão e no amor entre o homem e Deus" (FILORAMO; PRANDI, 1999, p. 257).

Nesse sentido, evidencia-se que o conceito de religião como o de "submissão a Deus" cristalizou-se no ocidente e estabeleceu as normas pelas quais o homem deve seguir para alcançar a Salvação. A religião cristã define-se como possuidora da única "verdade". Por isso, tudo o que lhe é contrário passa a ser entendido como mentira e deve ser combatido. Partindo da necessidade de explicitar o verdadeiro do falso, o sagrado do profano e o certo do errado, que surgiram os dogmas (a ortodoxia) e, consequentemente, as heresias.

Nessa perspectiva o presente artigo tem como objetivo realizar uma análise teórica acerca do processo pelo qual a heresia torna-se realidade. Pretendemos compreender como a ortodoxia "cria" a heresia e legitima, por meio de vários mecanismos de coerção, a intolerância. Tomamos como objeto de análise a atuação do tribunal do Santo Oficio, uma vez que fora o tribunal criado pela Igreja no intuito de combater as heresias que se haviam espalhado pela Europa desde o século XII.

Adotamos como metodologia a pesquisa descritiva e de natureza bibliográfica com abordagem qualitativa. Dessa forma, este estudo enquadra-se na perspectiva da História das Religiões, pois, de acordo com Sergio da Matta, a moderna História das Religiões “[...] ela quer - o que já é um desafio suficientemente grande - compreender e explicar geneticamente a religião nas suas relações com a sociedade e a cultura" (MATA, 2010, p. 17). Observa-se que, nas últimas décadas, o interesse da historiografia pelo campo religioso aumentou, os temas se ampliaram e, além da história econômica e política, muitos historiadores têm se dedicado ao estudo da cultura e das mentalidades. "Assim, jovens historiadores se aproximam de sociólogos e antropólogos no seu interesse pelo estudo da religião, segundo uma perspectiva histórica” (TORRES-LONDOÑO, 2013, p. 225).

Tomamos como referencial teórico a Análise do Discurso norteado por Michel Foucault (1996), que apresenta, pelo estudo da formação discursiva de cada momento histórico, a relação entre discurso e poder, considerando dispositivos de resistência e de controle do poder nas diferentes culturas e épocas históricas. Valemo-nos também do ensaio publicado por Georges Duby (1989), fruto da Conferência Internacional Colloque de Royaumont sobre "Heresias e Sociedades", realizado em maio de 1962. 
Este artigo está dividido em três momentos. Inicialmente, buscamos apresentar o conceito de heresia, conforme estruturado pela Igreja, a fim de estabelecer a diferença entre o pecador comum e o herege. Num segundo momento, procuramos analisar o papel social do herege, ou seja, trata-se de analisar o herege em seu meio, para perceber o discurso herético na sociedade. Por fim, pautamo-nos a estabelecer a relação dicotômica entre heresia e ortodoxia.

Acredita-se que este trabalho tem sua relevância, na medida em que aborda os mecanismos de coerção e de controle de poder em um dado momento histórico. Como principal resultado, pretendemos evidenciar que, para que haja a heresia, é fundamental o papel da ortodoxia. Ou seja, as heresias não nascem por oposição à religião, mas de dentro da própria religião, como uma resposta crítica a ela.

\section{Pecado e Heresia: definindo os limites}

Passemos, portanto, à compreensão do que vem a ser uma heresia e um herege do ponto de vista doutrinal. Ou seja, qual a diferença entre o pecador comum e o herege, bem como qual o papel do herege na sociedade do ponto de vista histórico.

Etimologicamente, a palavra heresia significa “escolher”, "preferir” (LOPEZ, 1993). No Catecismo da Igreja Católica, encontramos a seguinte definição:

Chama-se heresia a negação pertinaz, após a recepção do Batismo, de qualquer verdade que se deve crer com fé divina e católica, ou a dúvida pertinaz a respeito dessa verdade; apostasia, o repúdio total da fé cristã; cisma, a recusa de sujeição ao Sumo Pontífice ou da comunhão com os membros da Igreja a ele sujeitos (C.I.C, $2089)^{2}$.

$\mathrm{Na}$ esfera canônica, o herege é definido como o indivíduo que escolheu e "[...] isolou de uma verdade global uma verdade parcial e, em seguida, obstinou-se na escolha" (D.M. CHENU apud VAINFAS, 2014, p. 251). De acordo com o manual dos Inquisidores, herege é: "Aquele que adere [...] com convicção e obstinação a uma falsa doutrina considerada como verdadeira" (EYMERICH, 1993: p. 31). Ou seja, tratando-se da heresia, tão ou mais importante que os atos criminosos era a consciência do transgressor ao cometê-las. "Na heresia há recusa (ou pelo menos dúvida) a uma verdade que a Igreja ensina mas, para ser

\footnotetext{
${ }^{2}$ CATECISMO DA IGREJA CATÓLICA. $3^{\text {a }}$. ed. Petrópolis: Vozes; São Paulo: Paulinas, Loyola, Ave-Maria,
} 1993. 
classificado como herege, a pessoa deve, apesar de ter sido esclarecida, obstinar-se no erro" (GONZAGA,1993, p. 129).

Já a ortodoxia consiste na rigorosa observação dos dogmas religiosos. Dessa forma, Portella (2006) considera que, por mais ecumênica ou tolerante que seja, toda religião ou Igreja constituída, precisa colocar, de forma clara, as fronteiras entre ortodoxia e heresia, pois, caso contrário, tenderá a se esfacelar e perder a "legitimidade" de sua doutrina.

Nesse sentido, entendemos que o herege é aquele que contradiz as verdades da Igreja, não por tentação ou ignorância, mas por convicção pessoal. Lopez (1993) nos revela que, na Idade Média, as primeiras heresias surgiram no Oriente.

\begin{abstract}
Os primeiros considerados estão os gnósticos (que pretendiam a união do cristianismo com seitas místicas de origem helênica), os montanistas (que defendiam as tradições ascéticas e igualitárias dos primeiros cristãos), os donatistas (que defendiam um novo batizado para os apóstatas), os arianos (que diziam ser Cristo semelhante, mas não igual a Deus), os nestorianos (que afirmavam ter o filho de Deus se unido a um homem comum, Jesus) e os pelagianos (que afirmavam poderem os crentes se salvar, prescindindo da Igreja) (LOPEZ, 1993, p. 24-25).
\end{abstract}

Além das apresentadas, destacam-se as heresias que culminaram em 1054 no primeiro cisma do catolicismo: o "Cisma do Ocidente." Depois de uma troca de insultos, a Igreja Romana cortou ligações com a Igreja Bizantina excomungando o patriarca de Constantinopla Miguel Celulari. Muitos foram os motivos que levaram a esse racha no Cristianismo, entre eles questões políticas e econômicas. Porém as principais foram as heresias surgidas no catolicismo bizantino, denominadas Monofisismo e Iconoclastia.

Os membros do movimento monofisista defendiam que Cristo tinha apenas uma natureza divina, e não humana e divina como afirma a doutrina Católica. Já a iconoclastia (ou iconoclasmo) defendia a proibição das imagens de santos nas igrejas. Seus seguidores pregavam a destruição dessas imagens para impedir que elas fossem idolatradas.

Com o passar do tempo, o feudalismo foi sendo estruturado e o catolicismo se sobrepôs a todas as outras religiões que existiam na Europa antes da sua instituição como religião oficial. Assim, à medida que o feudalismo se firmava como sistema político, econômico e social, cresciam as suas formas de exploração e opressão. Com isso, as heresias perderam o seu sentido puramente doutrinal ou teológico e passaram a encerrar um sentido mais político. "Em determinado momento, a oposição ao feudalismo e a Igreja confluíram inevitavelmente para desencadear as heresias" (LOPEZ, 1993, p. 25). Para o referido autor, a heresia foi a resposta ao verdadeiro mal - um sistema social injusto e opressor, a que se juntava uma hierarquia eclesiástica onipotente e venal. 
São Tomás de Aquino apresentava a heresia sob três características conceituais: Doutrina, Pecado e Delito (SIQUEIRA, 2013, p. 198), ou seja, o pecado se configura como uma falta a Deus e aos seus mandamentos. Por tal razão, o pecado encontra sua remissão no confessionário, por meio da absolvição sacramental conferida pelo sacerdote unicamente ao pecador que humildemente reconhecia a sua falta e a apresenta ao confessor.

A origem do mal que movia o pecador para cometer o ato pecaminoso poderia ser de natureza humana, ou seja, uma tentação "carnal”, uma tentação demoníaca, ignorância ou omissão. Já a heresia possuía um caráter mais abrangente, pois se configurara como recusa ou dúvida a uma doutrina da Igreja. Ao colocar em dúvida a autoridade da Igreja, que era a base da sociedade feudal, o pecado torna-se um delito e passa a alçada não mais dos padres mais de juízes inquisidores. Assim se configura uma heresia.

No Santo Ofício contavam-se as heresias e apostasias. As heresias, i.e., todas as
doutrinas diretamente opostas ás verdades reveladas por Deus e propostas como tais
pela Igreja, manifestados por fatos, (palavra ou escrito), e as apostasias, i.e.
renegação total da fé, eram delitos. E porque eram delitos, refugiam ao campo da
jurisdição dos teólogos, para penetrarem no dos penalistas canônicos
(SIQUEIRA, 2013. p. 472, grifo nosso).

Para Sonia Siqueira, pioneira dos estudos inquisitoriais no Brasil, os pecados comuns possuíam um aspecto individual, já o pecado de heresia possuía um aspecto de coletividade, pois colocava em risco o bem estar da sociedade, "[...] Isso porque, num meio católico, as heresias e apostasias eram ameaças ao bem comum, uma vez que ameaçavam a integridade religiosa da sociedade pelo proselitismo dos hereges ou pelo escândalo que eles causavam. Afetavam a comunidade" (SIQUEIRA, 2013, p.472). E ainda “[...] A heresia era pecado pela sua própria matéria, porque ia buscar fora da Igreja sua regra de fé. Implicava em revolta consciente contra o magistério da Igreja, portanto no assentimento do espírito (2013, p. 198). A autora assim declara:

\begin{abstract}
A heresia era doutrina que se opunha imediatamente, diretamente e contraditoriamente a verdade revelada por Deus e proposta autenticamente como tal pela Igreja. [...] Era o pecado mais grave, porque supunha o mais completo conhecimento da regra de fé e da verdade a crer e implicava na mais radical oposição a revelação. Grave porque destruía a verdade da fé e consistia num soberana injúria feita diretamente a Deus. Feria a autoridade de Deus revelador manifestada pelo magistério da Igreja. A heresia era delito. Delito eclesiástico de ação ou omissão que perturbava a ordem da Igreja e tinha uma nocividade externa (SIQUEIRA, 2013, p. 198- 199, grifos nossos).
\end{abstract}

Com base nisso, pode-se compreender porque certos crimes não entravam na esfera dos processos inquisitoriais. 


\begin{abstract}
Ao Santo Ofício interessavam, fundamentalmente, os erros de doutrina passíveis de serem captados não apenas em afirmações ou ideias contestatórias a verdade oficial e divina, mas em atitudes ou comportamentos que por sua obstinação desafiadora aquela verdade, implicavam suspeita de heresia [...] Por isso, como veremos em detalhes, os inquisidores tomaram a seu cargo o julgamento dos bígamos, mas não o dos concubinatos; por isso perseguiram os sodomitas por vezes culpados do bestialismo, deixando os demais transgressores sexuais nas mãos de confessores ou tribunais diocesanos. Eleição arbitrária de "pecados heréticos" poder-se-ia com alguma razão afirmar-, mas sempre justificada com o argumento de que certos pecados eram tão graves que ameaçavam a pureza e a ordem da verdadeira fé (VAINFAS, 2014, p. 252, grifos nossos).
\end{abstract}

As heresias eram interpretadas pelos teólogos cristãos como uma doença espiritual de extrema gravidade. Por isso, os inquisidores agiam como verdadeiros "médicos", a fim de identificar as "doenças" da alma. "Os ministros do Tribunal procediam como um moderno analista, procurando compreender os processos psicológicos para apreender o sentido da falta" (SIQUEIRA, 2013, p. 477). Desse modo, a partir das confissões espontâneas ou forçadas, o réu poderia ser classificado em quatro categorias: heresiarca, crente, suspeito e faltosos

\begin{abstract}
"Heresiarca" é aquele que formula a doutrina heterodoxa e a difunde; o "crente" quem adere a essa doutrina; "suspeito" quem mostra simpatia pelos ensinamentos heréticos; "faltosos", quem aos hereges presta auxilio, mesmo sem abraçar a sua doutrina (GONZAGA, 1993, p. 130).
\end{abstract}

Classificavam-se ainda os hereges como impenitentes, penitentes e relapsos.

Chamam-se hereges tenazes e impenitentes aqueles que, solicitados pelos juízes, convencidos do erro contra a fé, intimados a confessar e abjurar, não querem submeter-se e preferem manter teimosamente seus erros. Estes devem ser entregues ao braço secular para serem executados. Chamam-se de hereges penitentes aqueles que, havendo aderido intelectualmente e de coração a heresia, retrocedem, têm piedade de si próprios, ouvem a voz da prudência e, abjurando seus erros e suas atuações anteriores, suportam as penas que lhes são infligidas pelo bispo ou pelo inquisidor. Chamam-se hereges relapsos, aqueles que, havendo abjurado a heresia e se tendo tornado penitentes, recaem na heresia. Estes, quando sua recaída é plena e claramente estabelecida, são livrados [sic!] ao braço secular para serem executados, sem necessidade de novo julgamento. Todavia, se eles se arrependem e confessam a fé católica, a Igreja lhes concede os sacramentos da penitência e da Eucaristia (GONZAGA, p. 130, grifos nossos).

Portanto, a fim de apurar a verdade, e descobrir a heresia e o grau de culpabilidade do réu, os interrogatórios do Santo Ofício eram verdadeiros esquadrinhamentos da vida, dos sentimentos, aspirações, medos e desejos mais ocultos dos que eram investigados. Questionava-se sobre a genealogia do réu, sua condição social, possível contato com outras religiões, seu conhecimento sobre a doutrina católica, com que pessoas convivera, onde se havia criado, etc. 
O caminho para atingir tal fim era o da compreensão das relações humanas, principalmente as afetivas. Importava realmente apurar a existência da heresia, não fossem as aparências induzir a juízos falseados. Por isso se interessavam eles também por atos moralmente bons, situações específicas em que as faltas tinham sido cometidas; saber se os implicados estavam em seu juízo perfeito, se não estavam tomados de vinho, ou se o costumavam fazer, e em que conta os tinha a opinião pública (SIQUEIRA, 2013, p. 478, grifos nossos).

Neste sentido, pode-se compreender porque a nomeação para o cargo de inquisidor precisava corresponder a algumas exigências, como, por exemplo, o Papa Clemente V (13051314), no Concilio de Viena (1311), dispôs que ninguém podia ser inquisidor antes dos quarenta anos. Também se exigia dos Inquisidores formação em Teologia e Direito Canônico, além de garantias de honestidade. Como doutor, o Inquisidor devia ter a competência para discernir a heresia onde
quer que despontasse, sob as mais inocentes aparências de que se pudesse revestir. A
mesma asserção, feita por diferentes pessoas, pode conter ou não a heresia. Um
exemplo: a afirmação que constantemente reponta das confissões feitas ao Santo
Ofício de que o estado dos casados era tão bom ou melhor que o dos religiosos. A
proposição fora proibida por Trento, podia no entanto, revelar apenas ignorância por
parte de quem repetia, podia ter sido fruto de conversas inconsequentes, mas podia
também esconder a heresia condenada (SIQUEIRA, 2013, p. 488).

Dessa forma, durante o procedimento inquisitorial, no momento em que estava perante o Inquisidor todos eram, por princípio, apenas "suspeitos de heresia". A investigação procedente deveria apurar se o sujeito era, de fato, herege ou apenas incorreu em práticas heréticas por ignorância. Caberia ao inquisidor apurar se o réu aceita ou não os ensinamentos da Igreja de formas consciente, o que exigia um alto nível de erudição por parte dos inquisidores para captarem a "pureza" do depoimento. A realização de uma prática, considerada herética era apenas o indício, o sintoma. No entanto, para ser considerado herege era preciso clareza acerca do ato praticado e, apesar de ser alertado, obstinar-se no erro.

\section{$2 \mathrm{O}$ herege no processo histórico}

Até o momneto discorremos acerca das definições sobre heresia na esfera canônica. No entanto, para uma análise da conjuntura social, cabe-nos buscar conceituar a heresia a partir da visão dos "vencidos", ou seja, aqueles cuja cultura oficial foi imposta. Trata-se de fato "[...] de observar o herege no processo histórico" (DUBY, 1989, p.176) e assim perceber o seu lugar social, dando-lhe a oportunidade de fala, condição indispensável para a compreensão da intolerância. 


\begin{abstract}
A maior parte daqueles que escreveram a história vista de baixo aceitariam em um sentido amplo a opinião de que um dos resultados de terem seguido essa abordagem tem sido demonstrar que, os membros das classes inferiores foram agentes, cujas ações afetaram o mundo (as vezes limitado) em que eles viviam. Voltamos a argumentação de Edward Thompson de que as pessoas comuns não eram apenas "um dos problemas com que o governo tinha de lidar" (SHARPE, 1992, p. 60, grifos nossos).
\end{abstract}

Concernente a isso, entendemos que: "o historiador está portanto autorizado a examinar em profundidade as reações da personalidade do heresiarca face ao seu meio; ele está autorizado a indagar sobre sua psicologia" (DUBY, 1989, p. 179). Salientamos que, para os historiadores da nova historiografia e diante do crescente interesse nas últimas décadas por novas abordagens historiográficas como a cultura, família, religião, etc., o acesso às informações de grupos marginalizados que há tempos foram silenciados pela historiografia oficial, é uma extraordinária realidade nos documentos inquisitoriais, que tem despertado o interesse de vários historiadores em trabalhos recentes, pois neles é dado o poder de fala às classes populares. Nessa medida, Lopez esclarece que: "o que foi identificado pela historiografia cristã como heresia, nas origens do cristianismo, a historiografia científica atual interpreta como sendo a visão dos vencidos" (LOPEZ, 1993, p. 24). E nas fontes inquisitoriais encontram-se grande quantidade de informação sobre esses grupos.

Oferecem, [as fontes inquisitoriais] no conjunto, não só a óbvia possibilidade de
análise das especificidades que calcavam a religiosidade e a fé da sociedade
colonial - como a ideologia religiosa, o imaginário da fé colonial, a atuação dos
clérigos e as práticas populares em suas principais representações e heresias -,
mas ainda indícios veementes sobre a estruturação econômica, política, cultural e
social das regiões visitadas, num leque que se estende das formas de moradia,
alimentação, festas e confraternização dos denunciados, confitentes e/ou
acusadores, até as intrigas na disputa pelo poder local, passando por feitiços de
amor, concubinatos, homoerotismo, vinganças pessoais ou assuntos do
cotidiano (ASSIS, 2004, p. 6, grifos nossos).

Inevitavelmente, deparamo-nos com uma dificuldade analítica, posto que os relatos dos personagens analisados nem sempre são objetivos, sendo relevante se levar em consideração que muitos deles partem do medo das pressões realizadas pelos inquisidores. Medo dos castigos, do banimento, do confisco de bens ou mesmo da morte.

O desejo de verdade por parte dos inquisidores (a verdade deles, naturalmente) produziu um testemunho extremamente rico para nós - profundamente destorcido, todavia, pelas pressões psicológicas e físicas que representavam um papel tão poderoso nos processos (GINZBURG, 1991, p. 12).

No entanto, o autor nos mostra que essas dificuldades não podem desencorajar os historiadores. "O fato de uma fonte não ser "objetiva" (mas nem mesmo um inventário é 
objetivo) não significa que seja inutilizável [...] Mesmo uma documentação exígua, dispersa e renitente pode, portanto, ser bem aproveitada" (GINZBURG, 2006, p. 16). O autor expõe, todavia, a necessidade de analisar a documentação inquisitorial pela utilização de filtros sobre o documento, tendo cuidado com as informações fornecidas pelas fontes.

\begin{abstract}
Eu não estou pretendendo naturalmente que esses documentos sejam neutros ou nos forneçam informações "objetivas". Eles devem ser lidos como o produto de uma inter-relação peculiar, claramente desequilibrada. No sentido de decifrá-los, devemos aprender a captar, por baixo da superfície uniforme do texto, uma interação sutil de ameaças e temores, de ataques e recuos. Devemos aprender a desencadear os diferentes fios que formam o tecido factual desses diálogos (GINZBURG, 1991, p. 15, grifos nossos).
\end{abstract}

Por essa razão, gostaríamos de conceituar adiante as heresias a partir do seu papel social, detectando o "perigo" que representava o discurso do herege para que deles se preocupasse tão intensamente o Santo Ofício. "Mas o que há enfim, de tão perigoso no fato de as pessoas falarem e de seus discursos proliferarem indefinidamente? Onde, afinal está o perigo?” (FOUCAULT 1999, p. 8). Em concordância com o que expomos até agora, percebese pelo caráter de crítica social que as heresias assumiram a partir da estruturação do feudalismo na Idade Média, os hereges passam à condição de perigosos, pois ameaçavam o sistema social vigente. "Protesto contra a pobreza, rebelião contra a autoridade, denúncia de corrupção eclesiástica, pregação evangelizadora para restaurar a pureza original do cristianismo, tudo isso se misturou para dar origem ao fenômeno herético" (LOPEZ, 1993, p. 25).

Entendemos, frente ao exposto, os hereges como aqueles que quebraram a "ordem do discurso" de seu tempo. Não estiveram inseridos nos paradigmas da época. E como explica Foucault (1999), o que não está na ordem do discurso não pode ser aceito. Por isso, sofreram interdição ou foram excluídos do convívio social. Pois, para que um discurso seja aceito em determinada época, faz-se necessário que ele obedeça "[...] as regras de uma 'polícia' discursiva, que devemos reativar em cada um de nossos discursos" (FOUCAULT, 1999, p.35). Para elucidar tal questão, o autor ilustra o caso de Mendel, que, mesmo falando a "verdade", sua teoria não foi aceita, uma vez que contrariava os preceitos da ciência do seu tempo histórico. "Mendel dizia a verdade, mas não estava 'no verdadeiro' do discurso biológico de sua época" (1999, p. 35).

O mesmo podemos dizer de homens e mulheres perseguidos pelo Santo Ofício, visto que eles não entravam na lógica do discurso sustentado pela sociedade da época em que viveram. Para Grigulevich, a Inquisição surgiu para combater a heresia enquanto ameaça à 
dominação vigente (apud LOPEZ, 1993, p. 15). Dessa forma, a heresia surge como um produto do seu meio, como uma quebra ou ruptura com as "verdades" estabelecidas pela sociedade em que ela atua como uma forma de rejeição ao discurso institucionalizado.

\title{
3 Heresia e ortodoxia
}

Segundo Foucault "a heresia e a ortodoxia não derivam de um exagero fanático dos mecanismos doutrinários, elas lhes pertencem fundamentalmente" (1999, p. 42). Ou seja, ao entender-se como a única religião possuidora da "única verdade", o catolicismo iria trabalhar no sentido de distinguir o verdadeiro do "falso", o bom do "mau", a religião da "heresia".

Os discursos e práticas particulares deveriam ser sistematicamente excluídos, proibidos, denunciados - tomados, tanto quanto possível, impensados, impensáveis; outros porém, deveriam ser incluídos, permitidos, celebrados e inseridos na narrativa sagrada (ASSAD, 2010, p. 268).

Corroborando com essa ideia também nos esclarece Duby: "é com efeito, a sentença de condenação pronunciada pelos clérigos que isola um corpo de crenças e lhe dá nome" (1989, p. 178). Isto é, o discurso da ortodoxia, consiste na denúncia que a própria Igreja fazia daquilo que procurava subverter a "verdade": seus dogmas e preceitos.

\begin{abstract}
A igreja Medieval não procurou estabelecer a uniformidade absoluta das práticas, pelo contrário, seu discurso autoritativo sempre se preocupou em especificar diferenças, gradações, exceções. O que ela buscava era a sujeição de toda prática a uma autoridade unificada, a uma fonte autêntica e única que pudesse distinguir a verdade da falsidade. Foram os antigos pais da Igreja que estabeleceram o princípio de que apenas uma Igreja unificada poderia se tornar o discurso autenticador (ASSAD, 2010, p. 269).
\end{abstract}

Algo peculiar recordado por Lopez (1993) é o fato de que alguns Santos da Igreja também possuíam em sua pregação certas afinidades com os discursos dos heréticos queimados nas fogueiras. O autor cita dois personagens: Santa Catarina de Sena e São Francisco de Assis: O caso de Santa Catarina é emblemático, pois ela verberou a imoralidade do papado de Avignon. "Obstinada e piedosa, foi, como outros santos da mesma estirpe, o reverso da medalha cuja outra fase era a heresia" (1993, p. 26).

Santa Catarina de Sena desempenhou um papel fundamental na história da Igreja, principalmente no que se refere ao episódio conhecido como "papado de Avignon", um momento dramático do Catolicismo em que, por razões políticas, o Papa se encontrava exilado em Avignon, na França. Catarina exortou o Sumo Pontífice a voltar para Roma. Ela obteve êxito já que o papa acata seu pedido em janeiro de 1377. Com seus ensinamentos, 
Catarina é sempre lembrada pelos seus biógrafos como uma jovem de personalidade forte e corajosa.

Quanto a São Francisco, seu discurso em muito se assemelhava com o de Arnaldo de Bréscia. Ambos pregadores mendicantes medievais, preocupados com a fortuna que a Igreja ostentava, pregavam a necessidade de uma Igreja mais pobre, a exemplo de Cristo, que foi pobre. Em face disso, cabe a pergunta: "porque São Francisco e ela [Catarina de Sena] ganharam a glória dos altares, e outros foram condenados? A razão está provavelmente, no fato de que eles, apesar de tudo, não desafiavam o sistema vigente" (LOPEZ,1993, p. 26). Ou seja, os hereges eram aqueles a quem faltava a "humildade". A mesma humildade que “salvou” Francisco, Catarina, Tereza D’Ávila e tantos outros que criticavam a Igreja, mas sempre de forma ponderada e até respeitosa, desejavam a mudança da Igreja por dentro, e não por fora.

\footnotetext{
Na verdade, a Igreja não poderia simplesmente condenar todos os movimentos que, na baixa Idade Média, clamaram por uma religião voltada ao povo e reformada em seus costumes. Aceitou aqueles que poderia aceitar e os utilizou como antídoto para as sua defesa - fabricou dois rótulos e, entre ambos ergueu a muralha intransponível - o santo e o herege (LOPEZ,1993, p. 26).
}

E assim compreendemos os princípios de exclusão e interdição do qual nos fala Foucault (1999). Os discursos de Francisco e Catarina não desafiavam o sistema vigente, pois buscavam uma "reforma" na Igreja de forma pacífica, por meio do diálogo com os líderes, sempre ancorados no princípio da obediência e da submissão. Dessa forma, sempre que a Igreja conseguia estabelecer o diálogo e "pacificar" o discurso herético, por meio da interdição imposta aos hereges, a heresia perdia sua criticidade, podendo reconciliada com a Igreja, cair no esquecimento ou em alguns casos, ser apropriado por ela, como nos casos acima mencionados. "Vimos que a ortodoxia suscitava a heresia, condenando-a e dando-lhe nome. Podemos perceber também, que a ortodoxia reabsorveu muitas heresias, domesticandoas, reconciliando-as consigo, apropriando-se delas” (DUBY, 1989, p.183).

Se essa pacificação da rebeldia do herege não acontecia, logo ele sofreria o princípio da exclusão, por meio do banimento, da prisão, ou do suplício no auto-de-fé. Recordamos o famoso caso de Domenico Scandella, apresentado pelo historiador Italiano Carlo Ginzburg (2006). A princípio, pareceu aos Inquisidores que haviam conseguido "domesticá-lo" persuadindo-o a obedecer a Igreja e reconhecer nos "absurdos" que havia falado, fruto de inspiração demoníaca. Domenico teria dito que “[...] a igreja não vai bem, e não deveria ter 
tanta pompa ${ }^{3 "}$ (GINZBURG, 2006, p. 128). Nas palavras dos seus acusadores, com sua desobediência ele "[...] criou uma nova seita e um novo modo de viver" (2006, p. 130). No final do processo, porém, Domenico escreve uma carta pedindo perdão, redimindo-se dos seus erros, expressando-se nestes termos:

Eu disse isso por vontade do falso espírito, o qual me cegara o intelecto, a
memória e a vontade, fazendo-me pensar, acreditar e falar no falso e não na
verdade $[\ldots]$ Entretanto, se eu pensei, acreditei, falei e fui contra os mandamentos
de Deus e da Santa Igreja, estou doente e aflito, arrependido e infeliz [...] Eu
prometo assim, não incorrer mais naqueles erros, ser obediente a todos os meus
superiores e pais espirituais em tudo o que eles me ordenarem e a nada mais
(GINZBURG, 2006, p. 140-142, grifos nossos).

Pela prova de reconhecimento de sua desobediência e rebeldia, após três anos de prisão, ele obteve a permissão para voltar à vida em sociedade, desde que mantivesse a mesma postura que expressara durante a prisão. No entanto, após um tempo de liberdade, a Inquisição novamente recebe queixas contra Domenico e ele volta a ser investigado e termina executado na fogueira. A história revela que muitos outros tiveram o mesmo destino.

A partir do século XVI, conforme Sônia Siqueira, as heresias que foram combatidas tornaram-se mais refinadas, pois, embora mantivessem o caráter de crítica ao sistema, a Igreja, a nobreza, etc., elas passaram a se esconder sob diferentes formas, disseminadas na sociedade sob diferentes rótulos, influenciadas pelo iluminismo, luteranismo, judaísmo, entre outros. "Talvez fossem mais graves porque se ocultavam, disfarçadas sob novas versões da espiritualidade cristã. O Santo Oficio combateu as novas mobilidades da heresia próprias dos tempos modernos" (SIQUEIRA, 2013, p. 201).

A autora esclarece que a Igreja da Reforma Católica foi uma Igreja de combate, mobilizada contra a heresia, por isso, apareceram traços novos. Dentre os "traços novos" aqui mencionados, ressalta-se o fator cristão novo, alvo principal das inquisições ibéricas, pois eram vistos como um perigo à unidade do reino e à hegemonia de um catolicismo abalado. A igreja após a Reforma torna-se ainda mais obstinada em sua missão de "salvar o mundo" dos perigos do judaísmo, luteranismo e tudo o mais que ameaçasse o seu poderio e a sua Doutrina.

Sabemos que um dos principais alvos de perseguição por parte do tribunal português foram os cristãos novos acusados de criptojudaísmo, isto é, a realização de ritos judaicos de forma clandestina, "secreta". No Brasil, muitos cristãos novos foram denunciados e processados pela Inquisição durante as visitas que aconteceram no período colonial: a primeira, em 1591 e 1595 , a segunda entre 1618 e 1621 , e a terceira entre 1627 e 1628 . As

\footnotetext{
${ }^{3}$ Mais uma heresia que se assemelha ao pensamento de São Francisco contra a fortuna da Igreja.
} 
práticas que sinomizavam a realização de ritos judaicos pela porção cristã nova da população eram variadas, desde guardar o sábado, até mesmo, vazar as águas dos potes que se conservavam em casa, quando do falecimento de alguém, rejeitar carne de porco, açoitar e até mesmo urinar sobre um crucifixo, dentre tantos outros costumes, conforme destacado por Ronaldo Vainfas:

[...] 1) guardar o sábado, vestindo-se com roupas e joias de festas, limpando a casa na sexta feira e ascendendo candeeiros limpos com mechas novas, mantendo-os acessos por toda a noite; 2) abster-se de comer toucinho, lebre, coelho, aves afogadas, polvo, enguia, arraia, congro, pescados sem escamas em geral; [...] 7) utilizar ritos funerários judaicos, a exemplo de comer em mesas baixas pescado, ovos e azeitonas quando morre gente na casa de judeus, amortalhar os defuntos com camisa comprida, enterrá-los em terra virgem, cotar-lhes as unhas para guarda-las, pondo lhes na boca uma pérola ou mesmo uma moeda de ouro ou prata e dizendolhes que é para pagar a primeira pousada, mandar lançar fora a água dos potes e vasos da casa quando alguém morre na casa (VAINFAS, 1997, p.22-23).

Nesse sentido, percebemos que o criptojudaísmo era visto pela Igreja como uma grave heresia uma vez que negava a divindade de Cristo, porquanto os judeus não aceitaram o messias Jesus. Em virtude disso, o discurso judaico era ameaça à própria base do cristianismo. A incorporação de elementos judaicos e as afirmações "blasfemas" dos cristãos novos contra a pessoa do Papa, contra os clérigos e até contra o Deus cristão, eram ameaças à unidade da fé pretendida pela coroa portuguesa.

Dessa forma, os criptojudeus, por seu comportamento desviante, punham em risco "a ordem" da sociedade colonial. Os cristãos novos ameaçavam o ideal de unidade cristã que ambicionava o reino português. "[...] eram os cristãos novos judaizantes que deveriam ser erradicados de suas heresias, porque eram elas que ameaçavam a unidade espiritual nacional" (SIQUEIRA, 2013, p. 183).

Não foram, no entanto, apenas os cristãos novos perseguidos pela Inquisição. Na realidade, todos os comportamentos que representassem alguma ameaça à ortodoxia da fé cristã foram combatidos. Conforme destaca Portela (2006, p. 571): “assim como no caso das prisões, pode-se aplicar às Instituições (Igreja) a questão da vigilância e punição na questão do zelo pela ortodoxia contra a heterodoxia do discurso e ação".

\section{Considerações finais}

Atualmente vivemos em uma sociedade cercada de discursos extremamente intolerantes. Discursos racistas, machistas e homofóbicos, de intolerância religiosa e 
discriminação social, que sobrevivem ao tempo e continuam se reproduzindo e ecoando perenemente seus efeitos devastadores ao longo dos séculos em nossa sociedade. De acordo com Cavalcanti (2015) acreditamos que o estudo de uma instituição intolerante como foi a Inquisição só faz sentido na medida em que atenta para sua capacidade de enraizamento cultural. Ou seja, trata-se de analisar os motivos pelos quais a intolerância passou a ser assimilada pelas pessoas.

Perguntas como estas não possuem respostas prontas, mas merecem atenção para uma reflexão cuidadosa acerca dos efeitos devastadores dos discursos que tendem ainda hoje a reascender as chamas de uma nova Inquisição, como nos alertou Hoornaert:

\footnotetext{
Os senhores da Inquisição eram capazes de construir verdades a respeito de judaísmo, heresia, superstição que impressionaram o povo por muito tempo [...] contudo nascem novas "verdades" que ninguém ousa contradizer por medo de repressão. Não se combate mais o judaísmo, a heresia, as superstições como antes. O combate é dirigido contra marxismo, fascismo, imperialismo, capitalismo, tudo o que incomoda ao grupo que está no poder, afinal de contas, ninguém explica a razão de ser dessas verdades, mas todos aceitam com medo. As instituições modernas repetem os estragos feitos na alma popular pela antiga Inquisição (HOONAERT, 1991, p. 57).
}

Dessa forma, consideramos que o estudo da Inquisição, “[...] todos nós o sentimos, desemboca no estudo da intolerância e das suas diversas motivações” (DUBY, 1989, p. 178). Acreditamos que o estudo do Santo Oficio traz à baila o problema da intolerância na história e vem demonstrar quão perigoso pode ser quando o discurso religioso se confunde com interesses políticos, dando margem a diversos problemas e conflitos.

\section{Referências bibliográficas:}

ASSAD, Talal. A construção da religião como uma categoria antropológica. Tradução de Bruno Reinhardt e Eduardo Dullo. Caderno de Campo São Paulo, v.19, no.19, p. 27-54, 2010.

ASSIS, Ângelo Adriano Faria de. A Inquisição no estudo sobre a Colônia. Anais do $5^{\circ}$ Encontro Perspectivas do Ensino de História, 2004. Disponível em:

<http://ojs.fe.unicamp.br/ged/FEH/article/view/5237>

BETHENCOURT, Francisco. História das inquisições: Portugal, Espanha e Itália. Séculos XIV-XIX. São Paulo: Companhia das Letras, 2004.

BURCKE, Peter (org). A escrita da História: novas perspectivas. Trad. Magda Lopes. São Paulo: UNESPE, 1992.

CATECISMO DA IGREJA CATÓLICA. $3^{\text {a }}$. ed. Petrópolis: Vozes; São Paulo: Paulinas, Loyola, Ave-Maria, 1993. 
DUBY, Georges. Idade Média, idade dos homens: do amor e outros ensaios. Trad. Jônatas Batista Neto. São Paulo: Companhia das Letras, 1989.

EYMERICH, Nicolau. Rio de Janeiro. Rosa dos Tempos; Brasília: EdUnB, 1993

FILORAMO, Giovani. PRANDI, Carlo. As Ciências das Religiões. São Paulo: Paulus, 1999.

FOUCAULT, Michel. Microfísica do poder. 22. ed. Rio de Janeiro: Graal, 2006.

Petrópolis: Vozes, 1987.

Vigiar e Punir: história da violência nas prisões. Trad. Lígia M. Ponde Vassalo.

A ordem do discurso. São Paulo: Loyola, 1996.

GONZAGA, João Bernardino. A inquisição em seu mundo. 4.ed. São Paulo: Saraiva, 1993.

GREEN, Toby. Inquisição: o reinado do medo. Rio de Janeiro: Objetiva, 2011.

GUINZBURG, Carlo. O queijo e os vermes: O cotidiano e as ideias de um moleiro perseguido pela inquisição. São Paulo: companhia das Letras, 2006.

n. 21, p. 09-20, 1991.

O Inquisidor como antropólogo. Revista brasileira de História, São Paulo, v.01,

LOPEZ, Luiz Roberto. História da Inquisição. Porto Alegre: Mercardo aberto, 1993.

MATA, Sérgio da. História e Religião. Belo Horizone: Autêntica Editora. 2010.

ORLANDI, Eni P. Análise do discurso: Princípios e procedimentos. 7.ed. Campinas, SP: Pontes, 2007.

PORTELLA, Rodrigo. Discurso Religioso, Legitimidade e Poder: algumas considerações a partir de Bourdieu, Foucault e Heller. Fragmentos de Cultura, Goiânia, v. 16, n. 7, p. 567576, 2006.

SHARPE, Jim. A história vista de baixo. In: A Escrita da história: novas perspectivas. BURKE, Peter (org.). São Paulo: Editora da Universidade Estadual Paulista, 1992.

SIQUEIRA, SONIA. O momento da Inquisição. João Pessoa: Editora Universitária UFPB, 2013.

TORRES-LONDOÑO, Fernando. História das religiões. In Compêndio de Ciência da Religião. PASSOS, João Décio; USARSKI, Frank (Org.) São Paulo-Paulus/Paulinas. 2013, p. 217-227.

VAINFAS, Ronaldo. Trópico dos pecados: moral, sexualidade e Inquisição no Brasil. Rio de Janeiro: Civilização Brasileira, 2014. 